\title{
LONG ISLAND, PAPUA NEW GUINEA - EUROPEAN EXPLORATION AND RECORDED CONTACTS TO THE END OF THE PACIFIC WAR
}

\author{
ELDON E. BALL \\ Department of Neurobiology, Research School of Biological Sciences, \\ Australian National University, Canberra
}

\section{SUMMARY}

William Dampier sailed past and named Long Island in 1700. His description of the island as green and well-vegetated indicates that the last major eruption of Long Island did not occur in the period 1670-1700. Dumont D'Urville sailed past in 1827 and from his description and those of others who came after him it appears that the eruption must have occurred before 1670 or in the interval 1700-1800.

Dampier in 1700 described a boat coming off from the shore of Crown Island and the Morrells in 1830 describe people and huts on the shore of Long Island, but the first reliable description of villages and the first contact with the people date from the visits of Finsch in 1884-5. Thereafter periodic brief contacts continued, at irregular intervals, up to the 1930's. Members of the German Südsee Expedition visited the village of Soraga in 1909 and collected names which provide a useful fixed point in the genealogies of the islanders. During the 1930's the ornithologist, William Coultas, spent several months on the island and there were periodic visits by Europeans interested in starting coconut plantations. World War II brought the islanders their most extensive contacts with the outside world as the island was first visited by a few small parties of Japanese and then in late 1943 it was occupied by an Allied force.

\section{HISTORY OF EUROPEAN EXPLORATION AND CONTACTS}

Records of knowledge about, or contact with, Long Island are important for the following reasons: they allow us to say with certainty that the last devastating eruption of Long did not occur during certain intervals and tell us something about the state of the vegetation on the island at certain dates; they allow us to say when people were first reliably described as living on the island and the names collected by the German expedition of 1909 provide a fixed point for dating the genealogies of the local people; and, we can gain some idea of the degree of outside contact experienced by the people and of the state of their culture at different dates. There are relatively few records of contacts before 1900, which has made it possible to present those which do exist essentially in full. Only in connection with contacts during World War II was more detail available than could be presented here.

Asian traders may have reached Long Island before the first Europeans but there is no definite record of this. A Malay kris, now lost, was found buried in association with a skull on Long Island and has been identified at the British Museum as dating from the 16th century (R. Caesar, pers. comm.), but its significance in terms of the history of the island is unknown since it could have been in use for a long period after its manufacture and it might have reached the island as a trade article. The possibility of early Asian imports to the north coast of New Guinea, either by visitors or via Melanesian canoe trading systems, has been discussed by Hughes (1977: 10-18). Also, Malays and Javanese were employed in considerable numbers in the Madang area in the late nineteenth and early twentieth century by the Germans (Hughes, 1977: 38). 